\title{
Critical Factors Influencing the Project Success in Pakistan
}

\author{
Aqeel Ahmad* \\ Department of Business Administration, Leads Business School, \\ Lahore Leads University, 5 Tipu Block New Garden Town Lahore, (Pakistan) \\ aqeel_pk@hotmail.com \\ Muhammad Sehail Younis \\ Department of Management, University of Haripur, Haripur (Pakistan) \\ Naveed Ahmad \\ Department of Business Administration, Leads Business School, \\ Lahore Leads University, 5 Tipu Block New Garden Town Lahore, (Pakistan) \\ naveeddgk2010@gmail.com
}

Naveed Anwar

Managing Director, Transcendent International Services

\section{Doi:10.5901/mjss.2015.v6n3p815}

\begin{abstract}
The objective of the current study is to analyze the importance of critical success factors with overall project success in the public sector of Pakistan. There are many factors which can influence the project success however the study focusing on soundness of business and workforce (SBW), planning \& control (PC), quality performance (QP) and past performance (PP). In this study it's reflected that major critical success factors can enhance the success of the project in the public sector of Pakistan. Based on the survey data collected the study founds, that there is a significant relationship among other critical success factors with overall project success. Among all the factors the planning and control is considered the highest relationship with overall project success. Furthermore, as perceived by the respondents there is significant evidence in general that the critical success factors in planning commission of Pakistan are below the average level and there is a vast scope to improve further. It is also concluded that the past performance in public sector organizations are lacking and need to improve further. Finally, the adapted model suggested that overall project success significantly relies on planning and control, soundness of business and workforce, and quality performance of the project.
\end{abstract}

Keywords: Critical Success Factors, Project Success, Public Sector of Pakistan, Quality, Performance

\section{Introduction}

All construction projects are unique and cover of unique difficulty and risks across many issues throughout the construction process. Increasing complexity in design and participation of various stakeholders in modern construction projects, add further challenges for both clients and contractors in matching the success factors and required capabilities to complete the project successfully (Uher and Runeson, 1984; Holt, Olomolaiye and Harris, 1995). Project success factors require special and permanent attention to guarantee a strong likelihood of project's success; otherwise, if these factors are not taken seriously, it could contribute to the failure of a project (Kandelousi and Abdollahi, 2011). In this study we will analyze and investigate critical success factors that influence the overall project success in public sector organization of Pakistan. Project management is conceptualized as the procedure of decision making and development of tools \& techniques for project success. For the success of any project, awareness and understanding of project management and critical success factors are must. Moreover, with scientific methods how they access and analyze these factors, and on the basis of this create probability to enhance the chances of a project success (Mobey and Parker, 2002). In Pakistan, Planning Commission of Pakistan is government body and responsible for development projects. Planning Commission works in all over the Pakistan. This body provides guidelines pertaining to project planning \& 
control, provide quality standards and monitoring system. To enhance the probability of success in projects good knowledge of critical success factors play a essential role, (Mobey and Parker, 2002). In this study it's reflected that major critical success factors and enhances the chances of project success in public sector of Pakistan.

\section{Purpose and Significance of the Study}

The purpose of the present study is first, to understand the relationship among the critical success factors (Soundness of Business Workforce, Planning Control, Quality Performance and Past Performance) with overall project success in public sector of Pakistan. Secondly, the study investigate those critical success factors which the respondents (full time employees) observe as the most significant and will require immediate attention. Finally, the study finds out the impact of critical success factors on overall project success. Critical success factors are needed to be measured to find its relationship and impact on overall project success and it becomes a significant area to study from the perspective of Pakistani public sectors organizations. The findings of the present study are also important for all the stakeholders (clients, project managers, contractors and consultants) to highlight the critical success factors to obtain the desired project outcomes. Moreover, the findings may be generalized to the other South Asian Association for Regional Cooperation (SAARC) countries because of the similarities of the region.

\section{Project Management}

In past studies we have seen literature of project manager and success but the critical factors impacting on project success are under research particularly in Pakistan. Many projects around the world keep failing, resulting in loss of millions of dollars for organizations. Looking into current challenging environment in the public sector organizations in Pakistan with new trends and technologies there is dire need the research on identifying the most critical success factors for project success in public sector organization of Pakistan.

Azzopardi (2009) stated project management as thousand years old practice dating back to the Egyptian epoch, however being used formally in organizations as a management tool in 1950's. The roots of project management originate from in two different planning and control in projects problems face in USA. This was the first ever experience with such projects that was not done earlier. Since neither cost nor time could have been accurately estimated the project was engulfed in huge uncertainties. Completion project dates were based on chances: optimism and pessimism. Program Evaluation Review Technique (PERT) was the great achievement of project experts. Practicing PERT resulted in creation of another methodology termed as (PPS) project planning and scheduling being launched by the private sector. It was considered more definite and realistic than PERT as it required realistic estimates of cost and time. The introduction of the personal computers with low cost software's for project management further improved and promoted the use of project management. Project management emerged as a separate discipline from diverse fields of application like engineering, construction, telecommunications, and defense. The 1950s era could simply be termed as the era of modern project management.

Presently, the culture of project based organization is common, organizations has divided their work in projects for quick growth of an organization. For organizational growth best management practices and \& techniques are necessary. We can analyze through individual project success that project is using right tools and techniques. Success is a very general but an attractive word and it is not easy to define, different people have different criteria of success (Muller and Turner, 2005). In his study the project success framework and consensus of different experts on project success. This topic is under discussion regularly from last many years (Baccarini, 1999).

\section{Critical Factors for Project Success}

The idea of critical success factors was introduced by Denial in 1961. The idea of critical success factors was more prominent when it was used to define that what are major critical factors for business or enterprise? After some time, in many areas the critical success factors was a major subject. Critical success factors are business approach (Rockart, 1979; Bruno and Leidecker 1984). It is discovered from the review of literature that a list of critical success factors and conclusion of Slevin and Pinto (1986) is the master piece of research work. Many researchers use this list for their study. This framework is very common and popular and they identified success factor (Muller and Turner, 2005). After detail review of literature we identified four variables soundness of business and workforce, project control, quality performance and past performance. we have explained briefly all the variables in next portion. 


\subsection{Project Planning \& Control on Project Success}

If we execute the project as per planning it does not mean that project will be successful. If the planning is faulty there will be many chances of project failure. If we use detail and quality planning then probability of success will be defiantly enhance. Many studies establish that planning is the major critical success factor (Johnson, 2001). Moreover, it is fact that planning is first step where we can develop plan and changers according to need. Till the time there is no major comprehensive tool to analyze the quality of planning. Project planning is the process of to develop project plan to meet project objectives (Meredith \& Mantel, 1995). Most important factor to manage the project is planning \& control. Moreover, success of project is also based on planning \& control. The major attributes of the planning are collect requirement, scope writing, tools \& techniques for cast, time and for other knowledge areas. Moreover, variance analysis and cast \& schedule are also important part of control. Detail planning decrease the chance of risks and failure. It's also support in forecasting for future projects. Project manager is the responsibility for project planning, he must assure the quality execution and understand stakeholders needs. We have seen a lot of work on project planning worldwide but in Pakistan there is a lack of research work on planning. In Pakistan, all public sector organizations are following planning commission standard and overall not proper slandered and practices for project planning. Even to improve these practices and implement international standard we have shortage of research work. In this situation we can say that there is need of study to identify the gap.

\subsection{Soundness of Business \& Workforce on Project Success}

Before defining soundness and workforce of business (SBW) we must understand that what performance management is. Simply, that SBW is the corporate performance, project team success, result oriented deliverables and consistency to achieve project objectives. Choi \& Zhao, (2005) defined SBW as in seven different factors namely capital for work, technical skills, liability, risk management, work experience, turnover, successful past performance. It is established that SWB can be defined smoothness of business and also establish that it is critical factor of project success. An established organization can produce better result. Until now, there are different concepts of soundness and workforce of business (SBW). Especially yearly profit and capital of a business can shows the soundness of an organization. Moreover, financial and also human turnover shows the sustainability and progress of the workforce. Usually, SBW consider as financial progress, security \& physical resources. Moreover, it also includes reputation and consistency of an organization. More study will defiantly add good value in this critical factor.

\subsection{Project Quality Performance on Project Success}

This globalization has created competitive environment all in business world (Adam, Flores \& Macias, 2001). This competitive environment, challenge oriented market, new ideas and work pressure create the Total Quality Management (TQM) (Ahire, Landeros \& Golhar, 1995). Management of quality and control quality has been recognized as critical factor in last decade. TQM has created significant impact on organizational performance and project success. The quality mean is not just minimize the cost and develop standard but also increase profit of the business. To check relationship detail study is important for researcher but also important for an organization. To implement the quality organization should give time for planning \& execution of quality. For said purpose organization introduce quality management practices. Quality is the satisfaction measurement criteria for every part of project deliverable. Arditi \& Gunaydin (1998) argue that management must focus on continuous quality management through control, training and other factors. Weak planning can also affect on project quality. Quality and performance both are correlated. Normally, quality measure through product standard, government standards, record keeping, query and action response and customer satisfaction (Hatush and Skitmore, 1997). Bubshait \& Al-Atiq (1999) explained that quality control is essential for preventing for success. Satisfaction of employees is one of the most critical factors in the success of project Razek (1998). Quality is the satisfaction measurement criteria for every part of project deliverable. It is established perceptions that different projects are not succeed and cannot complete within budget and timeframe or exceeds cost. Many projects cannot meet quality standers and customer requirements. Weak planning and low quality control are the major issues for project failure. In every project we can see the expected level of quality for deliverable.

\subsection{Past Performance and Project Success}

Performance reflects the status of an organization and also impact on the project success. March \& Sutton (1997) 
explained about different studies of performance management and effects. He said need more studies to analyze the impact of past performance on organization. The function of performance is common in term of management because it is a major factor in an organization so its definition is an organizational level is self explanatory (March and Sutton, 1997). In view of previous literature, success of project is based on time, budget and scope. According to Levin (2010) an enterprise or any company wants to deliver best products and services for their customers and to increase the sustainability of their projects. If an organization has experience and past performance is satisfactory, it will be the main factor for the success of project and this success automatically convert into organizational success. Owen (2011) argues that knowledge creation and past performance for improvement of the success of project $\&$ its maturity and knowledge creation on the basis of past performance and sharing activities are in active mode throughout the project from tacit and explicit level. Project team can reuse and capture knowledge at personal level. Presently, many organizations are project based organizations and strategies on project and project level. In project environment you can easily assess the performance. For future planning of projects and guidelines past projects performance is the key factor. In this study we also analyze the impact of past performance on project success in Pakistani public sector organization.

\section{Proposed Research Model}

The proposed research model shown in Figure 1 along with hypotheses comprises the four independent variables to assess the impact of overall project success as a dependent variable. The present study adopted the model from the previous research (Doloi, lyer and Sawhney, 2010).

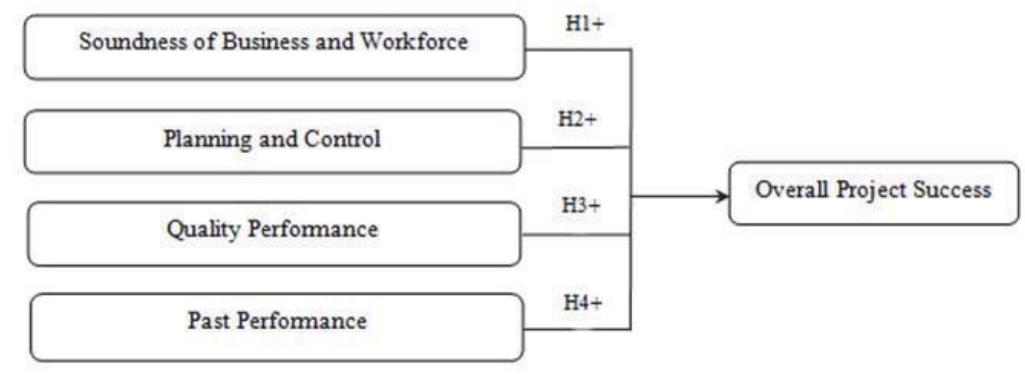

Figure 1: (Source: Doloi, lyer and Sawhney, 2010)

\section{Hypotheses}

H1. There is positive impact of Soundness of Business and Workforce on overall Project Success.

$\mathrm{H} 2$. There is positive impact of Planning \& Control on overall Project Success.

H3. There is positive impact of Quality Performance on overall Project Success.

H4. There is positive impact Past Performance on overall Project Success.

\section{Data Collection and Analysis}

Bhattacherjee (2012) argues that the survey research have inherent strengths compared to other research methods is ideally suited for remotely collecting data about a population that is too large to observe directly. To ensure consistency among all variables, present study measures all items using 1 to 5 points Likert scale except for the demographic data. The Likert scale is designed to examine how strongly the respondent agree or disagree with a certain statement (Sekaran, 2005). These 5 points scale, where 1=Strongly Disagree, 2=Disagree, 3=Neutral, 4=Agree, 5=Strongly Agree. This has been the most widely used method of scaling in the social sciences research. Moreover, this scale is much easier to construct, and much more reliable than other scales (Dumas, 1999). Survey questionnaire was used to collect the data and survey questionnaire used draws on a previous study (Doloi, lyer and Sawhney, 2010) and is adapted through appropriate modification to align with the Pakistani context which helps to create its ecological reliability and validity. The questionnaire comprised of two parts namely; Section 1) Overall project success comprised 4 items, planning \& control comprised 6 items, soundness of business \& workforce comprised 7 items, quality performance comprised 6 items and past performance comprised 6 items. Section 2) demographic information of the respondents and 
background section with 6 items; Therefore, the survey questionnaire contains total 35 items to achieve the present research objective. The survey questionnaire was distributed using snowballing technique. Before sending the final draft of the questionnaire, a pilot study was conducted to make sure the validity and reliability of the survey questionnaire. The value of Cronbach Alpha of all the constructs in the present study remained from 0.68 to 0.88 . Total 300 questionnaires were distributed from which 185 were received, eight were incomplete and 177 were considered for the analysis and the response rate was $59 \%$. The data was analyzed through SPSS latest version.

\section{Descriptive Statistics}

Table 1 shows the means score and indicate the extent the agreement level of the respondents'. In this study the descriptive analysis used as mean to describe the main features of the data. The constructs are calculated on a five point Likert scale of 1 to 5 , where 1 referred to "Strongly disagree" and 5 corresponds to "Strongly agree". Any scores that are below the midpoint (3.00) can be considered as low.

Table 1: Descriptive Statistics for the variables

\begin{tabular}{lcc}
\hline Variables & N & Mean \\
\hline Overall Project Success & 177 & 2.5791 \\
\hline Soundness of Business and Workforce & 177 & 3.1469 \\
Planning and Control & 177 & 2.9727 \\
Quality Performance & 177 & 3.2024 \\
Past performance & 177 & 2.8200
\end{tabular}

Table 1 shows that the highest mean score are 3.2 and 3.1 for quality performance and soundness of business and workforce respectively and as considered by the respondents. On the other hand, there seems to be a general perception among the respondents that other constructs (overall project success, planning and control and past performance) are below the average level.

\section{Correlation Analysis}

Pearson correlation analysis is significant to find association among variables. Sekaran (2005) has suggested the relationship will be perfect positive relationship among two variables if it is represented by +1 or perfect negative relationship if it will be represented by -1 . The correlation between the dependent variable (overall project success) and independent variables (soundness of business and workforce, planning \& control, quality performance and past performance) were run and depicted in Table 2.

Table 2: Relationship of OPS, SBE, PC, QP and PP

\begin{tabular}{lccccc}
\hline Variables & OPS & SBW & PC & QP & PP \\
\hline Overall Project Success (OPS) & 1 & & & & \\
Soundness of Business and Workforce (SBW) & .646 & 1 & & & \\
Planning and Control (PC) & .654 & .348 & 1 & & \\
Quality Performance (QP) & .536 & .419 & .247 & 1 & \\
Past Performance (PP) & .335 & .371 & .258 & .269 & 1 \\
**. Correlation is significant at the 0.01 level (2-tailed). & & & & &
\end{tabular}

Table 2 addresses the relationship among independent variables (SBW, PC, QP and PP) with dependent variable (OPS). The result depicted in the Table 4 that the planning and control and soundness of business and workforce has a significant correlation at $0.654(p<.000)$ and $0.646(p<.000)$ with overall project success respectively. We can further note that quality performance and past performance also correlation at $0.536(p<.000)$ and $0.335(p<.000)$ with overall project success respect.

\section{Regression}

The simple regression used to test all hypotheses $(\mathrm{H} 1$ to $\mathrm{H} 4)$ and the results of regression analysis are presented in 
Table 3.

Table 3: Model Summary and Regression Analysis

\begin{tabular}{|c|c|c|c|c|}
\hline \multicolumn{5}{|c|}{ Regression Statistics } \\
\hline Independent Variables & \multicolumn{3}{|c|}{ Regression Coefficient } & \\
\hline & Standardized $\beta$ & $\mathrm{T}$ & Sig. & \\
\hline Soundness of business and workforce & 0.646 & 9.629 & .000 & \\
\hline Planning and control & 0.654 & 8.460 & .000 & \\
\hline Quality performance & 0.335 & 6.452 & .015 & \\
\hline Past performance & 0.126 & 62.452 & .105 & \\
\hline Adjusted $\mathrm{R}^{2}$ & & & & 0.683 \\
\hline \multirow{2}{*}{ ANOVA } & $\mathrm{F}$ & & & 92.542 \\
\hline & Sig & & & $000^{*}$ \\
\hline
\end{tabular}

Dependent Variable: Overall Project Success

Table 3 indicates the influence of independent variables which are soundness of business and workforce (SBW), planning \& control (PC), quality performance (QP) and past performance (PP) on dependent variable overall project success (OPS). The $\mathrm{R}^{2}$ value (0.683) shows the goodness of fit of the model and is estimated as $68 \%$ which shows that $68 \%$ of variation in dependent variable is explained by independent variables. The standardized coefficients (Bs) reflect the change in the dependent measure for each unit change in the independent variable. In this study, the $\beta$ value for SBW, PC, QP and PP are 0.646, 0.654, 0.335 and 0.126 with significance at $(p<.000),(p<.000),(p<.015)$, and $(p<.105)$ respectively. The results shows for the impact envisaged in the $\mathrm{H} 1$ and $\mathrm{H} 4$ that are SBW, PC, QP and PP have a positive and significant impact on Overall project success.

\section{Discussions}

Project success factors require special and permanent attention to guarantee a strong likelihood of project's success; otherwise, if these factors are not taken seriously, it could contribute to the failure of a project (Kandelousi, 2011). Project success is a widely studied and discussed phenomenon of project management. While certain success criteria and success factors are common across different project types, there are unique criteria and factors that apply only to specific projects. (Dancsecz and Szabó, 2008). Identification of these underlying factors from the successful project delivery perspective and their relationships to the project functions should help both clients and constructors in achieving successful project outcomes (Doloi et al., 2010).

Given the above, our data provides sufficient evidence to respond to the objectives of the study. According to the respondents the planning and control has the highest correlation (with standardized coefficient $\beta=0.654$ ) with the overall project success. If we use quality planning then probability of success will be defiantly improve. Many studies establish that planning is the major factor and findings in line with the previous studies (Doloi, Iyer \& Sawhney, 2010; Johnson, 2001; Lo, Chao, Hadavi and Krizek, 1998; and Doloi, 2009). Moreover, it is fact that planning is first step where we can develop plan and changers according to need. Till the time there is no major comprehensive tool to analyze the quality of planning. Project planning is the process of to develop project plan to meet project objectives (Meredith \& Mantel, 1995). Most important factor to manage the project is planning \& control and success of project is also based on planning \& control. Generally projects complete on time but over cost and some project complete within cost but over time. When we monitor project we can see many deficiencies. To keep project on track project manager must avoid common and big mistake that is faulty planning. Therefore, the adequate planning is must for successful project. The influence of the soundness of business and workforce was found to be the second highest correlation (with standardized coefficient $=0.646$ ) on overall project success. Public sector projects have mega scope and for this they definitely need sound business and workforce, without SWB it's difficult to execute project properly. SBW is very important in the successful delivery of a project and findings of this study also support (Choi \& Zhao, 2005; Fong and Choi, 2000 and Okoroh and, Torrance, 1999). Government of Pakistan has development some standards for vendor so without sound business it's difficult to apply for any project. It is a fact that delay in releases is a common phenomena in public sector organizations, if organization is not financially stable it will be difficult for them to execute the project smoothly.

Among four critical success factors quality performance and past performance (with standardized coefficients 0.336 and 0.126 respectively) were found to have moderate / least correlation but direct influence on the overall project 
success. Quality management has created significant impact on organizational performance and project success. The quality mean is not just minimize the cost and develop standard but also increase profit of the business. Quality is the satisfaction measurement criteria for every part of project deliverable. Present study also support the earlier researchers (Kumaraswamy and Matthews, 2000; Palaneeswaran and Kumaraswamy, 2000) and have found moderate influence on overall project success. While, past performance of the organization is very important for the success of project. Levin, (2010) argues that any organization wants to deliver best products and services for their customers and to increase the sustainability of their projects. If an organization has experience and past performance is satisfactory, it will be the main factor for the success of project and this success automatically convert into organizational success. The present study has followed and supported (Hatush and Skitmore, 1997; Doloi, et al., 2010) that past performance is found to be the moderate / least important factor direly influences the overall project success. Many organizations are project based organizations and in project environment you can easily assess the performance. For future planning of projects and guidelines past projects performance is the key factor.

\section{Conclusion}

To recapitulate the paper attempts to address the issue of relationship among critical success factors and overall project success. Further, the paper attempts to see the impact of critical success factors on overall project success in the planning commission of Pakistan. The study founds, that there is a significant relationship among critical success factors (soundness of business and workforce, planning and control, project quality and past performance) with overall project success. In terms of relevance the project planning and control is considered the most significant relationship among all the critical success factors with overall project success. Further, there is significant evidence in general that the critical success factors in planning commission of Pakistan are below the average level and there is a vast scope of improving these critical success factors is needed as perceived by the respondents. The adapted model suggested that overall project success significantly relies on planning and control, soundness of business and workforce, and quality performance of the project.

\section{Future Research}

Looking in to the current challenging environment in public sector organizations in Pakistan with new trends and technologies, there is dire need the research on identifying the most critical success factors for project success in public sector organization of Pakistan. Critical success factors are needed to be measured to find its relationship and impact on project success and it becomes a significant area to study from the perspective of Pakistani public sectors organizations. The major findings has provided motivating insight into the concept of project success, however, a qualitative or case study based analysis need to further explore. The same study may be conducted elsewhere with a large sample size and would be more beneficial for practical estimations of impacts and more accuracy of findings for academician and practitioners.

\section{References}

Razek, A. R. H. (1998). Quality improvement in Egypt: methodology and implementation, Journal of Construction Engineering and Management, 124(5), 354-360

Adam, E.E., Flores, B.E. \& Macias, A. (2001). Quality improvement practices and the effect on manufacturing firm performance: evidence from Mexico and the USA. International Journal of Production Research, 39, 43-63.

Ahire, S. L., Landeros, R., \& Golhar, D. Y. (1995). Total quality management: a literature review and an agenda for future research. Production and Operations Management, 4(3), 277-306.

Arditi, D., \& Gunaydin, H. M. (1998). Factors that affect process quality in the lifecycle of building projects. Journal of Construction Engineering and Management, ASCE, 124 (3), 194203.

Azzopardi, A. J. (2009). What is the Mission of Your Project? Retrieved May 12, 2009, from. www.projectsmart.co.uk.

Baccarini, D. (1999). The logical framework method for defining project success. Project Management Journal, 30(4): 25-32.

Bhattacherjee, A. (2012). Social Science Research: Principles, Methods, and Practices, (2nd Ed.) Zurich: Global Text Project.

Bruno, A. \& Leidecker, J. (1984). Identifying and Using Critical Success Factors. In: Long Range Planning, 17(1), 23-32.

Bubshait, A. A. \& Al-Atiq, T. H. (1999). ISO 9000 quality standards in construction, ASCE Journal of Management in Engineering, 15(6), $41-46$.

Choi, Y., \& Zhao, J. L. (2005). Decomposition-based verification of cyclic workflows. In Automated Technology for Verification and Analysis (pp. 84-98). Springer Berlin Heidelberg.

Dancsecz, G., Szabó, L,(2008). Success Factors and Criteria of International Sport Event Projects, Proceedings of the 19th International 
DAAAM Symposium, DAAAM International, Vienna, 351-352.

Daniel, D. Ronald (1961). "Management Information Crisis," Harvard Business Review.

Doloi, H., (2009). Analysis of pre-qualification criteria in contractor selection and their impacts on project success. Construction Management and Economics 19, 1245-1263.

Dumas, J. (1999). Usability Testing Methods: Subjective Measures. American Institute for Research. www.upassoc.org

Fong, P.S.-W., Choi, S.K.-Y., (2000). Final contractor selection using the analytical hierarchy process. Construction Management \& Economics 18, 547-557.

Hatush, Z., Skitmore, M., (1997). Evaluating contractor prequalification data: selection criteria and project success factors. Construction Management \& Economics 15, 129.

Holt, G.D., Olomolaiye, P.O., Harris, F.C., (1995). A review of contractor selection practice in the U.K. construction industry. Building and Environment 30, 553-561.

Johnson, W. C. (2001). Business process orientation. Gaining the e-business competitive advantage Florida: St. Lucie Press.

Kandelousi, (2011). World Academy of Science, Engineering and Technology, 5,-11-24.

Kumaraswamy, M.M., Matthews, J.D., (2000). Improved subcontractor selection employing partnering principles. Journal ofManagement in Engineering 16, 47.

Kandelousi, N. S. \& Abdollahi, A. J. (2011). Key Success Factors for Managing Projects. World Academy of Science, Engineering and Technology, 5, 11-24.

Levin, J. (2010). Empirical Industrial Organization. Journal of Economic Perspectives, 24(2), 145-162.

Lo,W., Chao, C.H., Hadavi,A., Krizek, R.J., (1998). Contractor selection process for Taipei Mass Rapid Transit System. Journal of Management in Engineering 14, 57-65.

March, J. G., \& Sutton, R. I. (1997). Organizational Performance as a Dependent Variable. Organization Science, 8(6), 698-709.

Meredith, J. R. \& Mantel, S. J. (1995). Project Management. A Managerial Approach. (3ed) John Wiley \& Sons Inc. New York.

Mobey, A. \& Parker, D. (2002). Risk evaluation and its importance to project implementation. International Journal of Productivity and Performance Management, 51(4): 202-208.

Muller, R. \& Turner, R. (2005). The project manager's leadership style as a success factor on projects: A literature review. Project Management Journal, 36(2): 49-61

Okoroh, M.I., Torrance, V.B., (1999). A model for subcontractor selection in refurbishment projects. Construction Management \& Economics 17, 315-327.

Owen, L. (2011). Scandinavian Journal of Information Systems, 23(2), 85-108

Palaneeswaran, E., Kumaraswamy, M.M., (2000). Contractor selection for design/build projects. Journal of Construction Engineering and Management, 126, 331-339.

Rockart, J.F., (1979). Chief Executives Define Their Own Data Needs. Harvard Business Review, 57(2):81-93.

Sekaran, U. (2005). Research Methods for Business, a Skill Building Approach. (4th Ed.). New York: JohnWiley \& Sons, Inc.

Slevin, D.P. \& Pinto, J.K. (1986). The project implementation profile: new tool for project managers, Project Management Journal, 18 (4), 57-71.

Uher, T. E., Runeson, G., (1984). Pre-tender and post-tender negotiations in Australia. Construction Management and Economics 2 , 185-192. 